\title{
ISU AKSIOLOGI DALAM FILSAFAT ILMU KOMUNIKASI
}

\section{Muhammad Yunus}

STAI Bumi Silampari Lubuklinggau muhammadyunus@staibsllg.ac.id

\begin{tabular}{ll}
\hline & Abstrak \\
\hline Article History & This article describe axiologi issue in \\
Received: 15 Juni 2020 & communication philosophy. The \\
Revised: 18 Juni 2020 & problems that will be answered in \\
Accepted: 20 Juni 2020 & this study are: (1)What does the \\
\hline Keywords: & background which rise the debat on \\
Aksiologi & netralitiy of science?(2)What \\
Filsafat Ilmu Komunikasi & argumentation for those who have \\
& defferent perspective? (3) How this \\
& debat is overcome? This research \\
& find that term of value free in science \\
& originate from Helyocentris Theory \\
& that finded by Nicolause \\
& Coverniccus. This opinion have \\
& contradiction with Christian \\
& doctrine.This debat proceeds until \\
& Enstein and Positivisme philosophy \\
& era. Some of the scientist regard that \\
& science should be netral because it is \\
& an objective activity, conversly some \\
of expert declare that science must be \\
unnetrality. Science should be \\
developed considering morality. The \\
synthesis of these debat are that \\
netrality of science being on \\
justification level only, however \\
science is not netral when it is on \\
methodology and research object \\
choices.
\end{tabular}

\section{Pendahuluan}

Aksiologi merupakan cabang filsafat yang membahas tentang nilai atau disebut juga teori nilai (Jirzanah 2020, 5). Nilai sendiri adalah kualitas yang terdapat dalam suatu objek sehingga dapat 
dianggap sebagai bernilai atau tidak bernilai (Abidin 2011, 74). Manusia selalu menilai. Objek penilaian manusia itu adalah segala realitas, termasuk didalamnya adalah ilmu pegetahuan. Penilaian manusia terhadap ilmu pengetahuan ini tidak pernah tunggal dalam arti satu suara. Ilmu dalam pandangan orang saleh berbeda dengan pandangan saintist. Bila para agamawan memaknai ilmu sebagai nur atau cahaya Tuhan yang diberikan kepada manusia, maka bagi para saintis, ilmu adalah pengetahuan yang tersistem yang diperoleh dengan cara ilmiah. Disini sudut pandang subjek menghasilkan kemajemukan penilaian, pluralitas penilaian ini sebagai akibat dari dimensi sosio historis manusia (Frondizi 2011).

Ilmu berfungsi sebagai explanasi, prediksi dan kontrol. Dengan fungsinya sebagai explanasi ilmu dapat menggambarkan keadaan realitas secara empiris, serta dapat menunjukkan hubungan sebab akibat antar variabel. Begitu pula dengan fungsinya sebagai prediksi, yang memungkinkan manusia mampu meramal apa yang akan terjadi menyangkut alam dan lingkungan sosialnya. Dengan dua fungsi tersebut dan dilengkapi dengan fungsi ketiga akhirnya ilmu dapat mengendalikan keadaan. Sebagai contoh, bila manusia dapat menjelaskan hubungan antara banjir dan penggundulan hutan, maka dapat diramal secara akurat akan terjadinya banjir bila pohon-pohon ditebangi. Berdasarkan pengetahuan ini selanjutnya ilmuwan dapat melakukan kontrol lingkungan dengan cara reboisasi atau penghijauan kembali sebagai upaya pencegahan banjir. Hal yang sama seperti dalam kasus ledakan penduduk. Dalam contoh ini, ledakan penduduk dapat diatasi dengan program Keluarga Berencana $(\mathrm{KB})$, ini didasarkan pada pengetahuan bahwa kelahiran terjadi sebagai akibat menyatunya sperma dan sel telur. Untuk mencegah ini maka dianjurkan bagi pasangan suami istri mengikuti anjuran penggunaan kontrasepsi. Dari contoh ini terlihat bagaimana ilmu pengetahuan berfungsi.

Kini ilmu telah berkembang pesat. Perkembangan ini tentu saja membawa banyak kemudahan bagi kehidupan. Kemajuan dalam bidang transportasi memungkinkan manusia dapat berpindah dari satu tempat ketempat lain dalam waktu yang relatif singkat. Begitu pula dalam hal komunikasi dimana informasi dapat tersebar dalam hitungan detik. Semua ini sebagai dampak dari kemajuan ilmu dan teknologi. 
Meski suskses mempermudah kehidupan manusia, ilmu disisi lain ternyata tak selamanya membawa berkah, ia juga menimbulkan kutuk atau bencana (Jujun Surya Sumantri 2013). Ilmu yang semula bertujuan mempermudah kehidupan, perlahan tapi pasti bergeser pada penguasaan sesama. Ilmu tidak lagi menjadi alat mencapai tujuan, tetapi telah berubah sebagai tujuan itu sendiri. Berbagai peristiwa dehumanisasi timbul sebagai akibat penggunaan ilmu yang tidak mengindahkan kaidah-kaidah moral. Contoh yang sering ditampilkan dari penyalahgunaan ilmu ini adalah terjadinya dua perang dunia yang banyak mengorbankan nyawa tak bersalah. Kekecewaan terhadap penyalahgunaan ilmu ini disesali secara mendalam oleh Albert Entstein sebagai penemu cikal bakal pembuatan bom atom (Alfan 2013). Selain dari dua perang dunia diatas, gejala dehumanisasi juga bergulir saat munculnya isu obsesi para ilmuwan mengembangakan cloning pada manusia. Kemungkinan cloning pada manusia ini memang masih debatable, namun sudah dapat diramalkan bahwa ini akan berdampak pada penodaaan terhadap nilai-nilai kemanusiaan bila ini betul-betul diterapkan. Jika sebelumnya perkembangbiakan manusia melalui perkawinan, dengan teknologi cloning, sangat dimungkinkan bahwa manusia dapat diproduksi melalui proses rekayasa genetika tanpa jalur penikahan (Maharani 2008, 23). Disini nilai-nilai ikatan pernikahan sebagai sesuatu yang sakral tak lagi dihiraukan.

Fakta bahwa sifat destruktif dari penerapan ilmu ini, telah memunculkan isu-isu nilai dalam ilmu pengetahuan, termasuk dalam ilmu komunikasi. Dalam konteks filsafat ilmu komunikasi, isu-isu aksiologis ini muncul sebagai berikut: (1) Apakah teori bersifat netral atau tidak? (2) Apak ilmuwan mempengaruhi teori yang dihasilkan atau tidak? (3) Apakah ilmuwan memengaruhi proses sosial atau tidak? (Mufid 2018, 43). Isu ini bila dirangkum menjadi satu rumusan pertanyaan maka berbunyi "apakah ilmu komunikasi sebagai salah satu cabang ilmu pengetahuan bersifat bebas nilai atau tidak?". Pertanyaan tentang netralitas ilmu ini sebagai akibat tersadarkannya manusia bahwa dirinya telah teralienasi oleh ciptaanya sendiri (Alfan 2013, 145).

Isu aksiologis tentang netralitas dalam filsafat ilmu komunikasi ini adalah inti dari pembahasan yang hendak diteliti. Pertanyaan yang hendak dijawab adalah (1) bagaimana latar belakang munculnya 
perdebatan tentang netralitas dalam filsafat ilmu komunikasi? (2) Apa argumentasi masing-masing pihak yang berbeda pandangan? (3) Bagaimana perdebatan tersebut diatasi?.

Untuk menjawab beberapa pertanyaan tersebut, sumber data yang dijadikan rujukan adalah jurnal, buku-buku dan sumber dokumentasi lainya yang dipandang relevan dengan tema penelitian. Metode analisisnya meggunakan hermeneutika dengan unsur-unsur metodis deskripsi dan interpretasi (Zubair 1990).

\section{Pembahasan}

\section{Pengertian Netralitas Ilmu}

Istilah netralitas ilmu dimaknai sebagai ketidak berpihakan, otonom dan independen. Tidak berpihak kepada kebaikan maupun juga keburukan. Kebaikan dan keburukan dalam konteks netralitas ilmu ini, dianggap sebagai topik yang berada diluar persoalan ilmu (Burhanudin 2018). Netralitas berarti ilmu untuk ilmu. Ilmu tidak ada hubungannya dengan kepentingan tertentu. Singkatnya tugas ilmu hanya memproduksi pengetahuan.

Netralitas ilmu dalam arti tidak berpihak juga disamakan dengan "objektivitas". Objektivitas sendiri adalah suatu kondisi dimana subjek menjiplak realitas secara apa adanya. Kondisi ini adalah suatu keadaaan dimana ilmu terbebas dari nilai-nilai berupa budaya, agama dan kepentingan-kepentingan tertentu yang dibawa oleh subjek pengamat (Burhanudin 2018, 179). Subjek didepan objek hanya berperan sebagai peneliti yang kemudian menyimpulkan hasil pengamatannya itu berdasarkan data-data yang ia tangkap melalui pengalaman indrawinya. Subjekvitas pengamat tidak mempengaruhi hasil pengamatan. Situasi dimana ilmu pengetahuan manusia terbebas dari berbagai nilai inilah yang disebut sebagai netral atau bebas nilai (value free).

\section{Latar Belakang Perdebatan Tentang Netralitas Ilmu}

Sejarah perdebatan tentang netralitas ilmu setidaknya dapat diklasifikasikan kedalam tiga fase, yaitu fase penemuan Copernicus tentang kesemestaan, fase Albert Enstein tentang penemuan bom atom dan fase filsafat positivisme (Burhanudin 2018). Masing-masing fase ini dijelaskan dalam uraian berikut: 
Fase penemuan teori Heliocentris oleh Nicolaus Copernicus (14731543)

Berabad-abad lamanya manusia di belahan dunia telah meyakini kebenaran agama. Agama telah diterima sebagai sumber pengetahuan yang mutlak. Segala yang diberitakan oleh agama wajib diyakini dan mengandung pesan pengetahuan dari yang Maha Kuasa. Mengingkarinya berarti kesesatan dan kebinasaan. Bahkan terkadang informasi yang disampaikan agama dianggap sebagai suatu yang tidak memerlukan pembuktian empiris. Ia harus diterima tanpa protes. Manusia dengan keterbatasan nalarnya tidaklah dapat mengetahui detail keseluruhan semesta, sehingga agama hadir sebagai petunjuk memahami segala persoalan semesta.

Salah satu yang diyakini sebagai doktrin gereja yang final pada masanya adalah persoalan kesemestaan, tepatnya tentang astronomi. Sebagaimana ajaran kriten yang meyakini bahwa bumi adalah pusat tata surya, maka benda-benda langit berputar mengelilingi bumi sebagai pusatnya. Teori ini selanjutnya dinamakan dengan teori geocentris (Burhanudin 2018). Teori ini akhirnya tidak dapat dipertahankan sebagai penjelasan yang benar. Ia mendapat penentangan dari Nicolas Copernicus yang mencetuskan Helicenris Theory. Teori heliocentris untuk pertamakalinya dicetuskan oleh filusuf Yunani bernama Aristarchus pada abad ke-13, ia menyatakan bahwa matahari dikelilingi oleh bumi bukan sebaliknya. Namun anggapan ini masih bersifat hipotesis dan belum terdokumentasikan dalam bentuk tulisan. Teori Heliocentris selanjutnya mengalami perkembangan ditangan Nicolaus Copernicus. Melalui jasanya teori ini menunjukkan bukti bukti yang meyakinkan.

Sebagai antithesis geocentric, teori ini mendapatkan reaksi keras dari iman kristiani yang berasal dari inspirasi wahyu. Alhasil, temuan ini dianggap sebagai bid'ah agama yang harus ditolak. Meskipun ditentang gereja, teori heliocentris mendapat tanggapan positif dari filusuf-filusuf sesudahnya seperti Isac Newton (16421727 M), Galileo Galilei (1564-1642 M), serta Johannes Kepler (1571-1630 M) (Hambali 2013). Melalui observasi empiris mereka telah menumbangkan dogma Kristen tentang teori kesemestaan meskipun harus ditebus dengan inkuisi pengadilan Galileo Galilei.

Sejak kontradiksi sains dan agama muncul, persoalan netralitas ilmu semakin mencuat. Manusia merasa dapat menemukan kebenaran 
tanpa melalui ritus-ritus keagamaan. Agama yang semula sebagai sumber pengetahuan dianggap tidak relevan lagi untuk dipertahankan dalam memperoleh pengetahuan yang benar. Disini isu sains netral dimulai. Masa ini disebut sebagai renainsance yang bermakna kelahiran kembali. Zaman ini adalah masa dimana pengetahuan tidak lagi terikat pada otoritas politik dan agama, melainkan terletak pada nalar manusia (Munir 2008).

\section{Fase Penemuan Bom Atom oleh Albert Enstein (1439)}

Pada 2 Agustus 1439 M, Albert Enstein mengirim surat kepada peresiden Amerika Serikat Franklin D. Roosevelt mengenai usulan yang berhubungan dengan perang melawan Nazi. Dalam suratnya Enstein menyarakan beberapa kegiatan yang mengarahkan pada kegiatan pembuatan bom atom. Sebagai ilmuwan penemu formula $\mathrm{E}=\mathrm{mc}^{2}$ yang menjadi dasar pembuatan bom atom, ia lebih mengetahui dampak yang akan ditimbulkan dari penemuannya itu. Disini muncul persoalan nilai. Dari sikap Enstein tersebut timbul pertanyaan yaitu "Apa yang mendorong Enstein, sehingga merasa wajib unutuk membuat bom atom? Apakah karena ia warga Negara Amerika Serikat?, ataukah ia tidak suka dengan rezim Hitler?. Dalam suratnya itu Enstein menuliskan kekhawatiran Nazi membuat bom atom untuk tujuan perang. Seandainya pada waktu itu tidak ada tanda-tanda bagi jerman untuk membuat bom atom, mungkin Enstein tidak akan merekomendasikan idenya itu (Jujun Surya Sumantri 2013, 248).

Dari kasus ini terlihat bahwa Enstein pada akhirnya menunjukkan keberpihakannya kepada sekutu. Tetapi apakah keberpihakannya itu disebabkan oleh rasa nasionalisme atau patriotism?. Jawabannya tidak. Jawabannya adalah karena ia tidak ingin hasil penemuannya digunakan untuk menghabisi sesama. Keberpihakannya kepada sekutu menurut Jujun Sumantri adalah karena sekutu mewakili aspirasi kemanusiaan. Dalam pikirannya, seadainya sekutu kalah maka yang berkuasa adalah rezim Hitler yang kejam dan tidak berkeprimanusiaan.

Apa yang tercermin dalam sikap Enstein tersebut dapat dipahami bahwa pada saat-saat tertentu ilmuwan tidak bersikap netral. Para ilmuwan tidak menginginkan hasil temuannya tersebut digunakan untuk kepentingan yang justru menciderai kemanusiaan. 
Kemanusiaan tidak dibatasi oleh letak geografis, ras, suku bahkan agama. Dalam satu kondis yang menuntut penegakkan nilai-nilai kemanusiaan, ilmuwan tidak bersikap netral.

Fase Positivisme (1922-1929)

Positivisme adalah mazhab filsafat yang meyakini bahwa ilmu pengetahuan diperoleh melalui proses penalaran dan pengindraan. Aliran ini dipelopori oleh para filusuf yang menamakan diri sebagai lingkaran Wina (1922-1929) yang dipimpin oleh Moritz Schlick. Aliran ini menolak unsur subjektivitas dalam memperoleh kebenaran. Kebenaran bagi mereka adalah pengetahuan yang dapat diverifikasi oleh pengalaman empiris (Seran 2015). Positivisme mendobrak tradisi bios theretikos Yunani dalam memperoleh pengetahuan. Bios theoritikos dalam sejarah Yunani adalah metode mendapatkan pengetahuan melalui ritus-ritus keagamaan. Pengembangan konsep ontologis oleh positivisme dalam proses ilmu akhirnya mengantikan pendekatan mistis metafisik (Alfan 2013, 145).

Ilmu yang bebas nilai ini tidak hanya berlaku bagi ilmu-ilmu alam saja namun juga berlaku dalam ilmu-ilmu sosial. Bahkan positivisme dengan tegas menolak perbedaan metodologi antara ilmuilmu alam dengan ilmu sosial (Aceng Rahamat 2015). Bagi mereka sosiologi adalah bentuk lain dari fisika sosial (Watloly 2013). Konsep netralitas ilmu yang digagas oleh mazhab postivisme selanjutnya digugat oleh para filusuf Frankfurt seperti Herkheimer, Albert Marcuse, Theodor W. Adorno dan Jurgen Habermas. Mereka menentang keras klaim netralitas ilmu positivisme (Anas 2018)

\section{Perbedaan Argumentasi Tentang Netralitas Ilmu}

Terdapat beberapa pandangan tentang tema netralitas ilmu. Disatu pihak menghendaki sains netral sebagaimana yang telah diperlihatkan pada masa Copernicus. Dipihak lain berpendapat bahwa netralitas ilmu hanya terletak pada aspek metafisik ilmu, sementara pada level aksiologi ilmu harus digunakan dalam koridor moral (Jujun Surya Sumantri 2013). Berikut ini uraian tentang alasan masing-masing pandangan mengenai isu netralitas ilmu.

\section{Argumentasi Ilmu Bebas Nilai}


Pada uraian sebelumnya telah disinggung tentang padangan bahwa ilmu itu netral, sebagaimana yang kehendaki oleh mazhab positivisme. Pandangan ini diadasarkan pada argumentasiargumentasi dibawah ini:

- Pengamat mengambil jarak secara total terhadap objek pengamatan.

- Dengan kondisi berjarak secara total pada objek, pengamat berhadapan dengan realitas sebagai sebuah fakta yang netral.

- Melalui cara itu, ia dapat memanipulasi objek pada suatu percobaan dengan tujuan menemukan penegetahuan berdasarkan hukum causalitas.

- Hasil eksperimen adalah pengetahuan hukum-hukum pasti menurut pola deduktif-monologi.

- Teori yang diperoleh adalah pengetahuan yang bebas dari kepentingan dan dapat diaplikasikan secara teknis dan menyeluruh (Alfan 2013, 153)

Aguste Comte adalah salah satu tokoh dari mazhab positivistik yang konsekuen dengan padangan tentang ilmu tidak lagi dipengaruhi oleh persoalan mistik metafisik. Comte membagi perkembangan ilmu menjadi tiga tahap. Tahap pertama menurut Comte adalah tahap mistik atau agama. Pada tahap ini diumpamakan sebagai tahap anakanak, hal ini karena berbagai persoalan kehidupan dinisbahkan pada hal-hal irasional yang berbau mistik, serta menganggap bahwa dunia dirancang oleh roh atau dewa-dewa. Tahap kedua adalah tahap metafisik, ilmu pada tahap ini diumpamakannya sebagai manusia remaja, pada level ini alam semesta dihubungkan dengan unsurunsur non empiris. ini adalah tansisi dari level teologi menuju sains. Tahap ketiga adalah tahap dewasa. Pada level ini dunia tidak lagi diinterpretasikan sebagai susuatu yang memliki kekuatan mistik. Inilah tahap positif. Pada tahap ini penjelasan religius dan metafisik tidak lagi diperlukan. Ilmuwan dengan metode observasi dan eksperimen telah dapat menjelaskan hukum-hukum alam dengan akurat (Arif Rohman, Rukiyati 2014, 110)

\section{Argumentasi Ilmu Tidak Bebas Nilai}

Argumentasi yang mendasari pandangan ini adalah kenyataan bahwa ilmu tidak hanya bersifat kontruktif namun juga destruktif. Oleh karena itu ilmu dalam penerapannya perlu memperhatikan aspek 
moral. Ilmu harus diarahkan demi kebaikan hidup manusia. Asumsiasumsi dibawah ini adalah alasan mengapa ilmu harus terikat nilai:

- Sains secara faktual telah disalahgunakan manusia yang ditandai dengan terjadinya dua perang dunia yang memakan ribuan korban manusia tak bersalah.

- Para ilmuwan lebih tahu dampak negatif perkembangan ilmu, karena merupakan hasil penelitian secara terus menerus.

- Ilmu telah mengalami perkembangan pesat sehingga memungkinkan menodai kemanuisaan yang paling dasar sebagaimana yang terdapat dalam rekayasa genetika dan social engineering (Alfan 2013, 174).

Kenyataan diatas adalah beberapa alasan mengapa ilmu tidak bebas nilai. Perkembangan ilmu bukan sesuatu yang harus dihentikan, namun harus mengarah kepada kehidupan yang lebih baik.

Salah satu tokoh kelompok ini adalah Jurgen Habermas (1929). Habermas menolak postulat bahwa ilmu bebas nilai. Menurutnya setiap ilmu mempunyai kepentingannya masingmasing. Klaim bahwa ilmu bebas nilai sebagaimana asumsi postivisme bagi Habermas tidak dapat dibenarkan. Habermas mengklasifikasikan ilmu kedalam tiga kategori yitu, empiris analitik, historis hermeneutic dan ilmu-ilmu kritis (Supraja 2017). Ketiga jenis ilmu ini menurut Habermas meiliki kepentingan yang berbeda. Ilmu empris analitik berorientasi pada teknik instrumental. Melalui metode eksperimen, ilmu ini menghasilkan teknologi yang pada akhirnya diterapkan untuk memanipulasi alam dan memenuhi kebutuhan manusia. Ilmu-ilmu alam seperti fisika, kimia, biologi adalah ilmu-ilmu yang termasuk dalam kategori ilmu empiris analitik. Bila ilmu-ilmu empiris analitik berkepentingan untuk memenuhi kebutuhan material manusia melalui manipulasi alam, maka ilmu historis hermeneutic berkepentingangan unutk tujuan praktis. Kepentingan ilmu kategori kedua ini adalah untuk memahami persoalan kehidupan manusia. Metode yang digunakan adalah hermeneutika. Sejarah dan seni adalah dua disiplin yang masuk dalam kategori ini. Kategori ketiga dari pembagian ilmu menurut Habermas adalah ilmu-ilmu kritis. Kepentingan ilmu kritis adalah berupaya membebaskan manusia dari kesadaran palsu. Ketika ilmu analitis 
empiris dan historis hermeneutic membeku menjadi sebuah ideologi, maka ilmu jenis ketiga ini diperlukan sebagai upaya pembebasan. Kritik ideologi dan ilmu-ilmu sosial seperti ekonomi, politik dan filsafat adalah termasuk kedalam ilmu-ilmu kritis (Santoso 2015).

Habermas menyatakan bahwa postulat positivisme bahwa ilmu harus bebas nilai dalam rangka menghasilkan ilmu yang bersih dan murni dari kepentingan menunjukkan bahwa postivisme terjebak pada kepentingannya sendiri yaitu, kepentingan ilmu bebas nilai atau netral.

\section{Upaya Sintesis}

Setelah perdebatan panjang, akhirnya timbul upaya sintesis yang mengakhiri dua argumen yang bertolak belakang ini. Sintesis ini mengetengahkan dua alternatif yaitu context of discover dan context of justification (Febriani 2018, 131). Kedua alternantif ini adalah sebagai berikut:

\section{Context of Discover}

Dalam konteks discovery atau penemuan, ilmu tidak bebas nilai. Pada kondisi ini penemuan harus terikat pada kaidah-kaidah moral yang berlaku dimasyarakat. Sebagai contoh: seorang peneliti hendak meneliti pengaruh variabel film porno terhadap prilaku remaja, atas nama ilmu pengetahuan ia kemudian memilih metode eksperimen. Pada tahap awal dia mengelompok remaja kedalam dua kelompok yang terdiri dari kelompok eksperimen dan kelompok kontrol. Remaja kelompok eksperimen diberikan film-film porno sementara kelompok kontrol dberikan film-film bukan porno. Disini sipeneliti dalam memilih metode penelitiannya jelas mengabaikan aspek nilai. Meski atas nama sains, metode tersebut tentu saja suatu perbuatan asusila. Sipeneliti seharusnya tidak menggunakan metode eksperimen dalam penelitiannya, ia seharusnya memilih metode survey. Dari contoh ini jelas bahwa ilmu tidak bebas nilai. Ia harus dikembangkan dalam koridor nilai-nilai.

\section{Context of Justification}

Konteks jastifikasi bermakna bahwa suatu hasil penelitian harus diuji kebenarannaya. Pada level ini, produk keilmuan harus 
diungkapkan apa adanya. Hasil riset ini tidak boleh ditutup-tutupi atas nama apapun. Berdasarkan contoh tentang penelitian pengaruh pornografi yang menggunakan metode survey, hasil surveynya harus diungkapakan secara objektif. Pada aspek inilah ilmu pengetahuan dapat dikatakan sebagai bebas nilai.

Kenetralan ilmu menurut Jujun Sumantri disebabkan oleh pandangan para ilmuwan yang menganggap bahwa ilmu merupakan rangkai bagi penemuan pada tahap berikutnya. Perkembangan ilmu pengetahuan tidak berjalan secara acak melainkan sebuah proses kumulatif yang tertib dan runtut. Menutup rapat produk keilmuan adalah suatu kerugian besar. Hasil penemuan ilmu tidak boleh disembunyikan sepahit apapun hasilnya. Dalam hal inilah ilmu dapat dikatan nertral. Dalam hal lain seperti objek penelaahan dan aspek penggunaan ilmu, seorang ilmuwan harus berpihak pada pilihan moral tertentu (Jujun Surya Sumantri 2013, 251). Dengan upaya sintesis ini, perdebatan panjang tentang netralitas ilmu dapat diatasi.

Uraian Van Peursen dalam bukunya fakta, nilai dan peristiwa juga relevan untuk dijadikan pisau analisis mengenai hububungan antara ilmu pengetahuan dan etika. Realitas yang digumuli ilmu pengetahuan menurutnya tidak berhenti hanya pada persoalan fakta. Pembicaraan mengenai fakta sebagai objek ilmu akan bermuara pada persoalan nilai. Fakta tidak pernah diasalkan dari fakta. Fakta selalu diasalkan dari nilai sehingga dalam hal ini nilai adalah akar fakta. Fakta pada akhirnya akan menjadi fosil, yaitu fosil nilai (Peursen 1990, 62). Contoh bagaimana peralihan dari fakta kenilai ini, dideskripsikannya melalui gambaran tentang rambu-rambu lalu lintas (Peursen 1990, 20). Bila kita tanyakan apa sebenarnya rambu-rambu itu?, maka penjelasan kita tidak terhenti pada objek-objek material, semisal sebuah tiang dan lampu-lampu tiga warna. Realitas akhir dari rambu-rambu lalu lintas ini adalah persoalan etis. Penjelasan akhir tentang rambu lalulintas ini bukan pada objeknya melainkan fungsinya sebagai perintah ketertiban yang mengandung latar belakang nilai.

\section{Simpulan}

Term netralitas dalam ilmu komunikasi diartikan sebagai keadaan ilmu yang tidak dalam keberpihakan pada nilai-nilai dan atau 
otoritas apapun, baik yang berasal dari otoritas politik, agama dan tradisi masyarakat. Dalam perkembangan selanjutnya topik ini telah menyebabkan perdebatan panjang. Disatu pihak menganggap ilmu netral atau bebas nilai, dipihak lain muncul anggapan sebaliknya, yaitu ilmu tidak bebas nilai. Perdebatan ini muncul sejak penemuan teori heliocentric yang dicetuskan oleh Nicolaus Copernicus dan berlanjut sampai masa Esntein dan filsafat positivisme.

Golongan yang mengatakan bahwa ilmu pengetahuan bersifat bebas nilai didasari oleh anggapan bahwa ilmu bertujuan untuk menghasilkan penjelasan berbagai peristiwa secara objektif. Kelompok ini ingin meneruskan tradisi penemuan ilmu sebagaimana pada masa Galileo Galilei. Pada masa ini ilmu tidak terikat pada doktrin dan otoritas agama. Dilain pihak kelompok yang menginginkan bahwa ilmu tidak bebas nilai berdasarkan pada anggapan bahwa ilmu harus dikembangkan untuk kebaikan manusia. Fakta destruktif ilmu selama ini juga menjadi alasan perlunya ilmu yang tidak bebas nilai.

Perdebatan yang berlangsung lama ini, akhirnya menemukan sintesisnya. Netralitas ilmu terletak pada aspek jastifikasinya. Sedangkan pada level penemuan, metodelogi dan pemilihan objek penelaahannya, ilmu tidak bebas nilai. 


\section{DAFTAR PUSTAKA}

Abidin, Zainal. 2011. Pengantar FIlsafat Barat. Jakarta: Raja Grafindo Persada.

Aceng Rahamat, Et.al. 2015. Filsafat Ilmu Lanjutan. Jakarta: Prenada Media Group.

Alfan, Muhammad. 2013. Pengantar Filsafat Nilai. Pustaka Setia Bandung.

Anas, Mohamad. 2018. Rekonstruksi Epistemologi Ilmu Pengetahuan. Malang: Universitas Brawijaya Press.

Arif Rohman, Rukiyati, L Anriani. 2014. Epistemologi Dan Logika, Filsafat Untuk Pengembagan Pendidikan. Yogyakarta: UNY Press.

Burhanudin, Nunu. 2018. Filsafat Ilmu. Jakarta: Prenada Media Group.

Febriani, Dani Verdiansyah \&Erna. 2018. Filsafat Ilmu Komunikasi, Pengantar Ontologi, EPistemologi, Aksiologi. Jakarta: Indeks.

Frondizi, Risieri. 2011. Pengantar Filsafat Nilai. Yogyakarta: Pustaka Pelajar.

Hambali, Slamet. 2013. "Astronomi Islam Dan Teori Heliocentris Nicolaus Copernicus.” Al-Ahkam 23(2): 225.

Jirzanah. 2020. Aksiologi, Sebagai Dasar Pembinaan Kepribadian Dan Bangsa Indonesia. ed. Nadhila. Yogyakarta: Gadja Mada University Pers.

Jujun Surya Sumantri. 2013. Filsafat Ilmu, Sebuah Pengantar Populer. Jakarta: Pustaka Seminar Harapan. 
56 Muhammad Yunus, Isu Aksiologi dalam Filsafat Ilmu,....

Maharani, Septiana Dwiputri. 2008. Persoalan-Persoalan Nilai Dalam Klonasi Manusia. Yogyakarta: Kepel Press.

Mufid, Muhammad. 2018. Etika Dan Filsafat Komunikasi. Depok: Prenada Media Group.

Munir, Misnal. 2008. Aliran-Aliran Utama Filsafat Barat Kontemporer. Yogyakarta: Lima.

Peursen, C.A. Van. 1990. Fakta, Nilai Dan Peristiwa, Tentang Hubungan Antara Ilmu Pengetahuan Dan Etika. Jakarta: Gramedia.

Santoso, Listiyono. 2015. Epistemologi Kiri. Yogyakarta: Arruz Media.

Seran, T.M Surjanto Poespowardjo \& Alexander. 2015. Filsafat Ilmu Pengetahuan: Hakikat Ilmu Pengetahuan, Kritik Terhadap Visi Positivisme Dan Implikasinya. Jakarta: Kompas.

Supraja, Muhamad. 2017. Pengantar Metodologi Ilmu Sosial Kritis Jurgen Habermas. Yogyakarta: Gadjah Mada University Press.

Watloly, Aholiab. 2013. Sosio Epistemologi. Yogyakarta: Kanisius.

Zubair, Anton Bakker dan Achmad Charris. 1990. Metodologi Penelitian FIlsafat. Yogyakarta: Kanisius. 